BIODIK: Jurnal IImiah Pendidikan Biologi
ISSN 2580-0922 (online), ISSN 2460-2612 (print)
Volume 07, Nomor 03, Tahun 2021, Hal. 20-27
Available online at:
hiltps://online-journal.unja.ac.id/biodik

Research Article

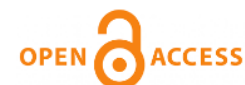

\title{
Efektivitas Metode Field Trip Dengan Aplikasi PlantNet Pada Materi Spermatophyta Sebagai Alternatif Inovasi Pembelajaran
}

\author{
(The Effectiveness of Field Trip Method Using PlantNet Applications on Spermatophyte \\ Concepts as an Alternative Learning Innovatio)
}

\begin{tabular}{|c|c|}
\hline \multicolumn{2}{|c|}{$\begin{array}{c}\text { Adnan Muchsin*, Zakia Nurfadilah, Riandi, Bambang Supriatno } \\
\text { Universitas Pendidikan Indonesia, Bandung } \\
\text { Jalan Dr. Setiabudi No. 229, Bandung 40415, Indonesia } \\
{ }^{*} \text { Corresponding Author:adnanmuchsin@upi.edu }\end{array}$} \\
\hline Informasi Artikel & ABSTRACT \\
\hline $\begin{array}{l}\text { Submit: } 07-06-2021 \\
\text { Diterima: } 14-08-2021 \\
\text { Dipublikasikan: } 14-09-2021\end{array}$ & $\begin{array}{l}\text { Learning system during a pandemic requires everything to be done online. This } \\
\text { is a challenge for teachers to continue applying certain learning methods without } \\
\text { eliminating the essence and purpose of the method. The innovation of the field } \\
\text { trip method with technology application is expected to be an alternative of } \\
\text { learning. Thus, this study aims to analyze the effectiveness of using the PlantNet } \\
\text { Application on identifying and classifying of Spermatophyte Plants. This study } \\
\text { used a qualitative descriptive method and the subjects of this research are high } \\
\text { school students of grade X. The analyzed aspects in this research are learning } \\
\text { outcomes, PlantNet use and user responses. The results of this study indicate } \\
\text { that } 88 \% \text { of students achieve good result and this can be stated as a successful } \\
\text { learning innovation based on individual completeness. Regarding the use of } \\
\text { PlantNet, almost all of the indicators received very good ratings by students. For } \\
\text { user responses, teachers and students have a good to very good response to } \\
\text { the use of the PlantNet application. } \\
\text { Key words: Innovation, Field Trip, Spermatophyte, PlantNet }\end{array}$ \\
\hline Penerbit & ABSTRAK \\
\hline $\begin{array}{l}\text { Program Studi Pendidikan Biologi } \\
\text { FKIP Universitas Jambi, } \\
\text { Jambi- Indonesia }\end{array}$ & $\begin{array}{l}\text { Pembelajaran di masa pandemi mengharuskan segala sesuatu dilakukan secara } \\
\text { daring. Hal ini menjadi tantangan bagi guru untuk tetap menerapkan metode } \\
\text { pembelajaran tertentu tanpa harus menghilangkan esensi dan tujuan dari } \\
\text { metode tersebut. Inovasi metode field trip dengan bantuan aplikasi diharapkan } \\
\text { menjadi sebuah alternatif pembelajaran. Sehingga, penelitian ini bertujuan untuk } \\
\text { menganalisis efektivitas penggunaan aplikasi PlantNet pada materi identifikasi } \\
\text { dan klasifikasi Spermatophyta. Penelitian ini menggunakan metode deskriptif } \\
\text { kualitatif dengan subjek penelitian Siswa SMA Kelas X. Aspek-aspek yang } \\
\text { dianalisis yaitu hasil belajar, fungsi PlantNet dan respon pengguna. Hasil } \\
\text { penelitian ini menunjukkan } 88 \% \text { siswa mencapai ketuntasan belajar atau lebih } \\
\text { dari ketuntasan individu } 85 \%, \text { sehingga pembelajaran dikatakan berhasil. Terkait } \\
\text { fungsi PlantNet, hampir semua indikator fungsi memperoleh penilaian yang } \\
\text { sangat baik oleh siswa. Untuk respon pengguna, guru dan siswa memiliki respon } \\
\text { yang baik hingga sangat baik terhadap penggunaan aplikasi PlantNet. } \\
\text { Kata kunci: Inovasi, Field Trip, Spermatophyta, PlantNet }\end{array}$ \\
\hline
\end{tabular}

This BIODIK : Jurnal IImiah Pendidikan Biologi is licensed under a CC BY-NC-SA (Creative Commons Attribution-ShareAlike 4.0 International License) 


\section{PENDAHULUAN}

Dalam proses belajar mengajar terdapat beberapa metode yang dapat merangsang kreativitas dan minat siswa terhadap pelajaran. Menurut Widia 2016), hasil belajar optimal dapat diperoleh siswa apabila siswa memaknai suatu pelajaran dengan baik bila mereka mengalaminya secara langsung. Selain itu menurut Thomas (2000) dalam Sunardi, dkk. (2015) siswa lebih tertarik melakukan sesuatu yang tidak berhubungan dengan peraturan dan prosedur di dalam kelas sehingga siswa merasa lebih mendapat kebebasan dalam belajar saat berada di luar ruangan kelas. Selain itu, suasana belajar di luar kelas cenderung berbeda dari kebiasaan belajar di dalam kelas sehingga siswa merasa tidak monoton.

Pembelajaran di luar sekolah melibatkan banyak karakteristik pembelajaran formal, seperti mengkonstruksi pengetahuan, karena memiliki banyak tantangan, baik diri sendiri maupun berkelompok (Tal, 2013). Dari berbagai metode pembelajaran yang diarahkan dengan memberdayakan semua potensi peserta didik untuk menguasai kompetensi yang diharapkan serta berpusat pada siswa diantaranya yaitu metode karyawisata (field trip). Menurut (Dillon, 2013), mengunjungi suatu lokasi diluar kelas memberikan kesempatan kepada siswa untuk mengembangkan keterampilan baru, mengobservasi spesimen secara langsung daripada menggunakan poto atau model sehingga mempertajam indera mereka. Menurut Rusel \& Ros., (2009), materi yang bisa dibelajarkan dengan field trip adalah materi yang terkait Tanaman, Warna daun, pucuk, biji, jenis-jenis rumput, gulma, dandelions, hewan bertulang belakang, burung, jejak hewan, insekta, beberapa artropoda dan jenis-jenis cacing

Berdasarkan hasil penelitian Bozdogan (2015) penerapan field trip pada 260 Mahasiswa Biologi dari berbagai Universitas Pendidikan di Turki, dapat meningkatkan kemampuan merencanakan dan berorganisasi sehingga memberi dampak pada keterampilan di luar kelas siswa ketika menghadapi lingkungan kerja. Sehingga hal tersebut memiliki pengaruh jangka panjang hingga terkait karir siswa. Sedangkan menurut hasil penelitian Astriani., (2018) field trip dapat meningkatkan kompetensi sains 76 mahasiswa Pendidikan IPA di Unesa, Semarang. Hal ini karena keterlibatan siswa dalam menginderai semua yang terjadi dilapangan secara langsung.

Sedangkan pada tingkat sekolah beberapa penelitian menunjukkan hasil yang positif dengan penggunaan metode tersebut. Misalnya hasil penelitian Nurmaliah, (2019) yang menunjukkan penerapan metode karyawisata dapat meningkatkan minat belajar 72 siswa MTsN Model di Banda Aceh, kelas VII khususnya untuk materi keanekaragaman hayati dan upaya pelestariannya. Selain itu hasil penelitian Rugaiya (2019) terkait kemampuan menulis siswa dengan menggunakan Strategi field trip dapat meningkatkan kemampuan menulis deskriptif 30 mahasiswa semester 2 di Universitas Riau.

Namun pada masa pandemi saat ini, melakukan kegiatan karyawisata adalah hal yang melanggar protokol kesehatan. Selain itu, siswa yang sehari-hari praktikum dengan aplikasi seperti Virtual Lab tidak memberikan pengalaman secara langsung bagi siswa, tidak pada satu mata pelajaran tetapi mata pelajaran lainnya. Hal ini sejalan dengan hasil penelitian Ambusaidi et al., (2017)yang mengindikasikan bahwa Virtual Lab tidak memberi dampak signifikan pada perilaku sains siswa. Hal ini disebabkan karena siswa tidak terlibat dengan fenomena ilmiah pada kondisi nyata (Lunetta et al., 2007). Selain itu tuntutan pembelajaran abad 21 saat ini, tentu menjadi beban bagi guru ketika tidak melakukan pembelajaran secara langsung.

Teknologi merupakan hal yang sangat penting bagi siswa saat mempelajari segala sesuatu di sekolah (Akbar \& Noviani, 2019). Pendidikan yang semakin hari semakin diperlukan, memaksa perlu adanya suatu teknologi untuk memenuhi kebutuhan siswa (Sultoni, 2015). Salah satu teknologi yang diperlukan untuk memenuhi kebutuhan siswa saat ini adalah aplikasi PlantNet. Aplikasi PlantNet yaitu aplikasi 
berbasis android untuk mengidentifikasi spesies suatu tumbuhan yang tidak hanya dapat membantu ahli botani dalam menjalankan pekerjaannya tetapi juga membantu pendidik dan peserta didik untuk memudahkan dalam mengidentifikasi spesies suatu tumbuhan (Guo \& Gao, 2017). Aplikasi ini dirancang untuk mengidentifikasi dan lebih memahami semua jenis tanaman yang hidup di alam, tanaman berbunga, pohon, rumput, tumbuhan runjung, pakis, tanaman merambat, kaktus, dan sejumlah besar tanaman budidaya (di taman dan kebun) meskipun ini bukan tujuan utamanya (Pujianto et al., 2020).

Salah satu materi kelas $X$ yang terkait dengan identifikasi tanaman untuk pembelajaran siswa yaitu materi Spermatophyta. Materi ini merupakan materi yang mengajarkan siswa terkait kelompok tanaman biji yang lebih tinggi, yang kehilangan spermatozoa flagellata dan mengembangkan tabung serbuk sari (Fitri Yeni \& Marlina, 2016). Macam-macam tanaman ini mudah dijumpai oleh siswa dilingkungan sekitar misalnya di taman, pinggir jalan atau kebun. Dengan demikian, kegiatan field trip mandiri yang dilakukan oleh siswa tidak harus ke Kebun Raya Bogor atau Kebun Raya Bali, atau Kebun Botanii terkenal lainnya. Dengan demikian inovasi metode ini diharapkan bisa mewadahi siswa SMAN 4 Praya Lombok Tengah, untuk melakukan field trip secara langsung (bukan melalui virtual lab) tanpa melanggar protokol kesehatan namun tetap memberi pengalaman belajar yang berarti. Untuk itu penelitian ini dilakukan untuk melihat efektivitas penggunaan aplikasi PlantNet terhadap hasil belajar dan respon siswa SMAN 4 Praya pada materi Spermatophyta dengan menggunakan aplikasi PlantNet.

\section{METODE PENELITIAN}

Penelitian ini menggunakan metode penelitian kualitatif deskriptif. Subjek dalam penelitian ini yaitu siswa Kelas X SMAN 4 Praya (Lombok Tengah) sebanyak 42 orang dan 4 orang guru Pengampu Mata Pelajaran Biologi. Tahap penelitian dimulai dari (1) tahap perencanaan yang melibatkan guru pengampu Mapel Biologi di sekolah, (2) tahap persiapan yang melibatkan guru dan siswa, (3) tahap penelitian dan (4) laporan hasil penelitian. Pada tahap perencanaan, peneliti bersama guru melakukan identifikasi permasalahan terkait penggunaan aplikasi pada materi tertentu dan permasalahan pembelajaran materi Spermatophyta sebelumnya. Pada tahap persiapan, peneliti dan guru memberikan pembekalan terkait pembelajaran dengan metode karyawisata, tutorial aplikasi PlantNet, penyusunan skenario pembelajaran, LKS, soal evaluasi dan penyusunan instrumen angket/kuisioner. Pada tahap penelitian, pembelajaran dengan metode karyawisata dilakukan secara online menggunakan Network Interface agar dapat dilakukan monitoring secara real time. Siswa melakukan karyawisata di dekat rumah, kebun, taman komplek atau lapangan secara bersamaan seperti karywisata sebenarnya dan tetap terkoneksi.

Adapun komponen-komponen yang akan diobservasi dalam penelitian ini yaitu (1) hasil belajar (2) fungsi PlantNet, dan (3) respon pengguna (siswa dan guru). Masing-masing komponen terdiri dari beberapa indikator yang dirumuskan bersama antara peneliti dan guru di sekolah. Data hasil belajar diperoleh dari hasil evaluasi terkait identifikasi dan klasifikasi tanaman Spermatophyta. Untuk data angket fungsi PlantNet dan respon pengguna, dijaring melalui layanan google form setelah pembelajaran selesai. Tahap terakhir peneliti melakukan analisis data hasil penelitian, diskusi dengan beberapa guru dan menyusun laporan. Analisis data hasil belajar dilakukan dengan melihat ketuntasan belajar individual, sedangkan analisis data terkait fungsi aplikasi dan respon pengguna dilakukan dengan pemberian skor berdasarkan rubrik penilaian, persentase dan katagori seperti yang dilakukan oleh Ricky, dkk. (2020) dan Prasvita \& Herdiyeni, (2013). 


\section{HASIL PENELITIAN DAN PEMBAHASAN}

\section{Hasil Belajar}

Menurut Kunandar (2013), hasil belajar merupakan kompetensi baik berupa kognitif, afektif maupun psikomotorik yang dicapai oleh siswa setelah mengikuti proses belajar mengajar. Dalam hal ini, hasil belajar siswa yaitu kemampuan siswa dalam mengidentifikasi dan mengklasifikasi tumbuhan Spermatophyta menggunakan aplikasi PlantNet. Ketuntasan tersebut didasarkan pada nilai Kriteria Ketuntasan Minimal (KKM) Mata Pelajaran Biologi. Dari hasil evaluasi siswa, didapat data ketuntasan hasil belajar seperti pada tabel 1 .

Tabel 1. Persentase ketuntasan hasil belajar siswa

\begin{tabular}{lcc}
\hline Kriteria Nilai Ketuntasan Belajar & Frekuensi & Persentase \\
& & \\
\hline Tuntas (Lebih dari 70) & 37 & $88 \%$ \\
\hline Tidak Tuntas (Kurang dari 70) & 5 & $12 \%$ \\
\hline Jumlah & 42 & $100 \%$ \\
\hline
\end{tabular}

Berdasarkan tabel di atas, 88\% siswa dinyatakan tuntas atau mendapat nilai lebih dari 70 pada materi Spermatophyta. Menurut Rosana et al., (2017)suatu pembelajaran dikatakan berhasil apabila 85\% siswa di kelas mencapai ketuntasan individu. Maka, berdasarkan data pada tabel tersebut, pembelajaran Spermatophyta dengan aplikasi PlantNet dikatan berhasil. Hal ini sejalan dengan hasil penelitian Ricky et al., (2020) yang berhasil menggunakan aplikasi PlantNet untuk meningkatkan kemampuan siswa pada klasifikasi mahluk hidup pada mahasiswa semester 4 jurusan Tadris IPA Universitas Jember.

Pada materi Spermatophyta, soal yang diberikan kepada siswa kelas $X$ berupa soal essay terkait kemampuan mengidentifikasi tanaman dan mengklasifikasinnya. Ada beberapa faktor yang mempengaruhi hasil belajar seseorang menurut Rusman (2013) yaitu faktor internal terkait jasmani rohani siswa, faktor eksternal terkait kondisi lingkungan siswa dan faktor pendekatan belajar terkait strategi dan metode. Faktor pendekatan merupakan suatu kondisi yang bisa di manipulasi oleh guru atau dosen. Dalam hal ini, terkait metode yang digunakan yaitu metode karya wisata (field trip) dengan menggunakan aplikasi PlantNet yang dilakukan secara daring. Hal ini dilakukan untuk membuat siswa memiliki pengalaman belajar yang baru sehingga lebih menitikberatkan pada pembelajaran yang bermakna. Siswa tidak hanya daring di dalam rumah tetapi juga bisa di luar ruangan layaknya sedang karyawisata tetapi tetap terkoneksi dengan peserta didik lain dan guru.

\section{Fungsi PlantNet}

Joly et. al. (2016) mengatakan bahwa aplikasi PlantNet merupakan aplikasi yang terbuka untuk umum dan bisa diakses oleh siapa saja dan kapan saja, melalui web atau aplikasi seluler dan identifikasi datanya berbasis gambar. Dalam mengoperasikan aplikasi ini, dibutuhkan data internet yang tidak terlalu besar sehingga terjangkau oleh siapapun. Berdasarkan beberapa pertimbangan terkait permasalahan dalam penggunaan aplikasi maka dirumuskan 4 indikator terkait fungsi PlantNet yang diobservasi pada penelitian ini yaitu (1) display/tampilan (2) fitur aplikasi (3) kemudahan mengoperasikan dan (4) hasil identifikasi. Data responden yang didapat dari setiap indikator disajikan pada diagram lingkaran pada gambar 1. 

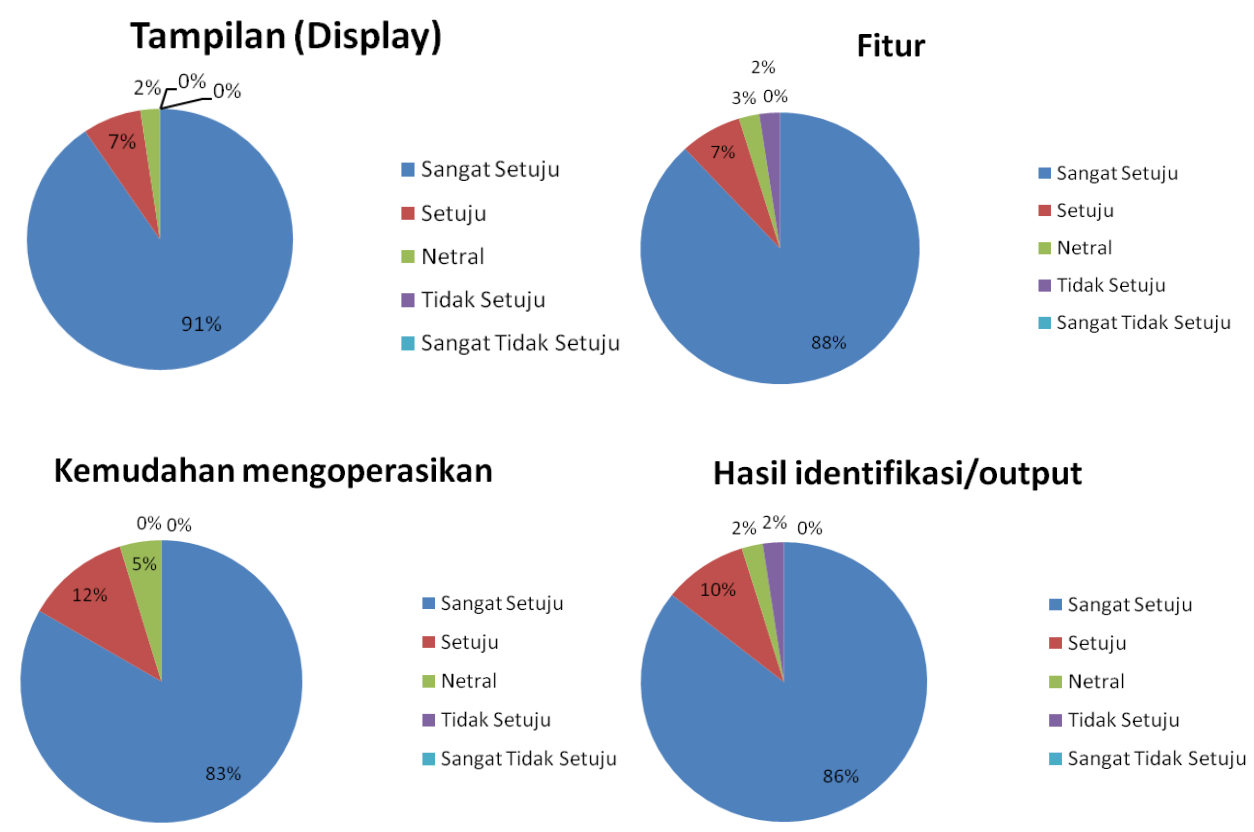

Gambar 1. Diagram lingkaran 4 indikator terkait fungsi aplikasi PlantNet

Berdasarkan gambar 1, dari 4 indikator yang diobservasi pada subjek siswa Kelas $\mathrm{X}$ dapat dikatakan bahwa semua indikator terkait fungsi aplikasi memiliki penilaian yang sangat baik oleh siswa. Dari segi tampilan, 91\% siswa sangat setuju bahwa aplikasi PlantNet memiliki tampilan yang menarik dan sederhana. Aplikasi didominasi oleh warna hijau dan langsung terhubung dengan gambar-gambar hasil identifikasi terbaru pemilik akun lain dan tersusun berdasarkan abjad. Untuk fitur, 88\% siswa sangat setuju bahwa aplikasi ini memiliki fitur-fitur yang sederhana dan praktis. Kamera yang langsung terhubung dengan objek dapat mengidentifikasi nama dan klasifikasi tumbuhan hanya dalam beberapa detik. Hasil penelitian Le et al., (2014) bahwa daun merupakan bagian tanaman yang banyak digunakan untuk identifikasi karena datanya lebih banyak. Selain itu menurut Goeau et. al. (2013) dalam Ricky et al., (2020) pada PlantNet data identifikasi mencakup takson, identitas kelas, detail waktu pengamatan dan pemilik gambar.

Untuk indikator kemudahan mengoperasikan aplikasi, 83\% siswa sangat setuju bahwa aplikasi PlantNet mudah digunakan. Hal ini berkaitan dengan indikator sebelumnya yaitu fitur aplikasi. Selain itu indikator output/hasil identifikasi $86 \%$ siswa sangat setuju bahwa hasilnya cepat dan akurat. Hal ini didasarkan pada beberapa gambar dari akun-akun sebelumnya yang mengidentifikasi tanaman sejenis dan penilaian oleh akun-akun lain (Ricky, dkk. 2020). Selain itu identifikasi juga bisa dilakukan dari gambar yang tersimpan pada galeri handphone (Prasvita \& Herdiyeni, 2013).

\section{Respon Pengguna}

Pada aspek ini, data pada setiap indikator diperoleh dari 2 kelompok pengguna yaitu siswa dan guru. Jumlah responden siswa sebanyak 42 orang dan responden guru sebanyak 4 orang. Masing-masing kelompok responden mengisi kuisioner yang berbeda namun berkaitan, karena merupakan pandangan mereka terhadap aplikasi sebagai kelompok belajar dan kelompok pengajar. Berikut data perolehan ratarata respon hasil pengisian kuisioner pada setiap indikator dari kelompok siswa yang dikatagorikan menurut hasil penelitian (Ricky et al., 2020). 
Tabel 2. Persentase rata-rata respon setiap indikator pada kelompok siswa

\begin{tabular}{clcc}
\hline $\begin{array}{c}\text { Kelompok } \\
\text { Responden }\end{array}$ & \multicolumn{1}{c}{ Indikator } & $\begin{array}{c}\text { Rata-rata } \\
\text { Respon }\end{array}$ & Katagori \\
\hline \multirow{3}{*}{ Siswa } & Semangat belajar & $85 \%$ & Sangat Baik \\
\cline { 2 - 4 } & Belajar tidak monoton & $90 \%$ & Sangat Baik \\
\cline { 2 - 4 } & Kemudahan belajar & $85 \%$ & Sangat Baik \\
\cline { 2 - 4 } & Belajar mandiri & $85 \%$ & Sangat Baik \\
\cline { 2 - 4 } & Hasil belajar & $80 \%$ & Baik \\
\hline
\end{tabular}

Berdasarkan tabel 2, semua indikator tergolong katagori sangat baik kecuali indikator hasil belajar pada katagori baik. Hal ini menunjukkan bahwa siswa memiliki respon sangat baik terhadap penggunaan aplikasi PlantNet. Siswa merasa terbantu ketika melakukan identifikasi dan klasifikasii tanpa harus mengeksport gambar ke google, modul atau website identifikasi khusus tanaman, sehingga mencari informasi terkait dari literatur lain menjadi lebih mudah. Hal ini sejalan dengan hasil penelitian Pujianto et al., (2020) yang menyatakan bahwa aplikasi PlantNet memperlihatkan adanya pengaruh positif pada pembelajaran IPA pada siswa kelas VII. Selain itu, Sugandi et al., (2020) menyatakan bahwa mahasiswa sangat terbantu oleh aplikasi PlantNet dalam melakukan identifikasi morfologi daun. Jadi, aplikasi ini sangat membantu dalam proses dan hasil belajar yang berdampak signifikan pada semangat dan motivasi siswa.

Pada kelompok responden guru, kuisioner yang diberikan terkait beberapa indikator sepertii alternatif field trip, inovasi baru (pada tingkat sekolah), kemudahan mengajar, kontrol orang tua, dan peningkatan hasil belajar siswa. Data perolehan rata-rata respon pada setiap indikator dari pengisian kuisioner oleh kelompok guru disajikan pada tabel 3.

Tabel 3. Persentase rata-rata respon setiap indikator pada kelompok guru

\begin{tabular}{clcc}
\hline \multirow{2}{*}{$\begin{array}{c}\text { Kelompok } \\
\text { Responden }\end{array}$} & \multicolumn{1}{c}{ Indikator } & Respon & Katagori \\
\hline \multirow{3}{*}{ Guru } & Alternatif field trip & $75 \%$ & Baik \\
\cline { 2 - 4 } & Inovasi baru & $80 \%$ & Baik \\
\cline { 2 - 4 } & Kemudahan mengajar & $85 \%$ & Sangat Baik \\
\cline { 2 - 4 } & Kontrol orang tua & $80 \%$ & Baik \\
\cline { 2 - 4 } & Peningkatan hasil belajar & $80 \%$ & Baik \\
\hline
\end{tabular}

Berdasarkan data pada tabel 3, hampir semua indikator mendapat respon pada katagori baik, kecuali pada indikator kemudahan belajar. Hal ini menunjukkan bahwa penggunaan aplikasi PlantNet di kalangan guru mendapat respon baik. Aplikasi tersebut bisa menjadi alternatif pembelajaran dalam melibatkan siswa secara langsung selama Pandemi ini, sehingga mempermudah guru dalam mengajar. Aplikasi ini tidak hanya melibatkan minds on saja seperti virtual lab tetapi juga hands on siswa sepertii memilih dan menempatkan spesimen yang mirip untuk mengurangi kesalahan identifikasi, sehingga lebih memberi pengalaman secara nyata. Menurut Pujianto et al., (2020) bahwa aplikasi ini tidak hanya digunakan oleh mahasiswa tetapi juga oleh tenaga pendidik seperti guru IPA atau guru Biologi. Hal ini untuk mempermudah mereka mengarahkan siswa terkait penggunaan (simulasi) atau dalam menemukan modul sebagai pembanding karena aplikasi ini tidak selamanya benar. Hal ini disebabkan oleh ada 
beberapa tumbuhan yang memiliki bagian yang mirip sehingga memungkinkan terjadinya kesalahan identifikasi. Maka peran guru sangat dibutuhkan dalam meluruskan kesalahan konsep.

\section{SIMPULAN}

Dari penelitian ini dapat disimpulkan bahwa penggunaan aplikasi PlantNet terhadap hasil belajar dan motivasi siswa Kelas X SMAN 4 Praya (Lombok Tengah) pada materi Identifikasi dan Klasifikasi tanaman Spermatophyta memberi dampak positif terhadap hasil belajar dan motivasi siswa. Inovasi ini akan membuat pembelajaran dengan metode karyawisata pada saat pandemi, bisa dilakukan meskipun tanpa harus mengunjungi tempat yang jauh atau menggunakan video di youtube. Sehingga, siswa tetap bisa melakukan pembelajaran yang bermakna dengan bantuan aplikasi PlantNet. Meskipun begitu, peran guru dalam mengarahkan dan mendampingi proses identifikasi oleh siswa tetap diperlukan, mengingat aplikasi tersebut tidak selamanya benar karena ada beberapa bagian tumbuhan yang memiliki bentuk yang mirip sehingga kesalahan identifikasi menyebabkan kesalahan konsep. Hasil penelitian ini mengindikasikan bahwa aplikasi PlantNet telah menjadi teknologi yang baik dan mengantarkan siswa, guru dan orang tua pada dunia digitalisasi yang mendidik sebagai alternatif atau inovasi pembelajaran dengan melibatkan teknologi pendukung lainnya.

\section{UCAPAN TERIMA KASIH}

Ucapan terima kasih kepada Bapak Dr. Riandi, M.Si dan Bapak Dr. Bambang Supriatno, M.Si., Prof. Dr. Yayan Sanjaya, M.Si., dan Lembaga Pengelola Dana Pendidikan (Kemenkeu) yang telah mendukung secara materil.

\section{RUJUKAN}

Akbar, W., \& Astriani., D. (2018). Bryological exploration: field-trip based learning to develop competencies of science teacher candidate. International Conference on Science Education (ICOSEd) IOP Publishing IOP Conf. Series: Journal of Physics: Conf. Series. https://doi.org/10.1088/1742-6596/1006/1/012006

Akbar, A., \& Noviani, N. (2019). Tantangan dan Solusi dalam Perkembangan Teknologi Pendidikan di Indonesia. Prosiding Seminar Nasional Pendidikan Program Pascasarjana Universitas Pgri Palembang, 2(1), 18-25.

Ambusaidi, A., Ali, A., Balushi, S., \& Balushi, K. (2017). The Impact of Virtual Lab Learning Experiences on 9th Grade Students' Achievement and Their Attitudes Towards Science and Learning by Virtual Lab. Journal of Turkish Science Education., 15(2), 13-29.

Bozdogan, A. (2015). Determination of Biology Department Students' Past Field Trip Experiences and Examination of Their Self-Efficacy Beliefs in Planning and Organising Educational Field Trips. Wulfenia Journal, 22(7).

Dillon, J. (2013). Science, the Environment and Education Beyond the Classroom. In B. Fraser; K. Tobin \& C. McRobbie (Ed.). In Second international handbook of science education (pp. 1081-1095). Springer.

Fitri Yeni, L., \& Marlina Program Studi Pendidikan Biologi FKIP Untan, R. (2016). Pengaruh Model Inkuiri Terhadap Hasil Belajar Siswa Pada Sub Materi Spermatophyta Kelas X. 1-14.

Guo, P., \& Gao, Q. (2017). A Multi-Organ Plant Identification Method Using Convolutional Neural Networks. Proceedings of the IEEE International Conference on Software Engineering and Service Sciences, ICSESS. https://doi.org/https://doi.org/10.1109/ICSESS.2017.8342935

Kunandar. (2013). Penilaian Autentik (Penilaian Hasil Belajar Peserta Didik Berdasarkan Kurikulum 2013. PT. Rajagrafindo Persada.

Le, T. L., Tran, D. T., \& Hoang, V. N. (2014). Fully automatic leaf-based plant identification, application 
for Vietnamese medicinal plant search. Proceedings of the Fifth Symposium on Information and Communication Technology - $\quad$ SolCT, 14, 146-154. https://doi.org/htps:/doi.org/10.1145/2676585.2676592

Lunetta, V. N., Hofstein, A., \& Clough, M. P. (2007). Learning and teaching in the school science laboratory: an analysis of research, theory, and practice. In S. K. Abell, \& N. H. Lederman (Eds.). In Handbook of research on science education (pp. 393-441). Lawrence Erlbaum Associates.

Nurmaliah. (2019). Penggunaan metode karyawisata untuk meningkatkan pemahaman Konsep pada materi keanekaragaman hayati dan upaya Pelestariannya. Jurnal Biotik, 7(1), 80-88. issn: 23379812

Prasvita, D. S., \& Herdiyeni, Y. (2013). MedLeaf: Mobile Application for Medicinal Plant Identification Based on Leaf Image. International Journal on Advanced Science, Engineering and Information Technology, 3(2), 103. https://doi.org/htps:/doi.org/10.18517/ijaseit.3.2.287

Pujianto, A. A., Degeng, I. N. S., \& Sugito, S. (2020). Pengaruh penggunaan aplikasi Plantnet dan gaya belajar terhadap hasil belajar. Jurnal Inovasi Teknologi Pendidikan, 7(1), 12-22. https://doi.org/10.21831/jitp.v7i1.31365

Ricky, R., Alvarizi, F., \& Hasanah, R. (2020). Persepsi Mahasiswa Dalam Menggunakan Aplikasi PlantNet Pada Mata Kuliah Klasifikasi Makhluk Hidup. VEKTOR: Jurnal Pendidikan IPA, 1(1).

Rosana, D., Ramadani, M., \& Dewi, K. (2017). The Instrument for Assessing the Performance of Science Process Skills Based on Nature of Science (NOS). Cakrawala Pendidikan: Jurnal IImiah Pendidikan, 36(3), 435-445. https://doi.org/10.21831/cp.v36i3.14731

Rusel, \& Ros., H. (2009). Ten-Minute Field Trips. A Teacher's Guide to Using the Scholgrounds for Environmental Studies. In Second Edition. National Science Teachers Asociation. Special Publications.

Rusman, R. (2013). Faktor-faktor yang mempengaruhi hasil belajar. Bumi Aksara.

Soendari, T. (2012). Metode Penelitian Deskriptif. UPI Press.

Sugandi, M., Rasyid, A., AA., G., \& Sugianto. (2020). Aplikasi PlantNet Sebagai Media Identifikasi Morfologi Daun Berbasis Android di Masa AKB. Seminar Nasional Pendidikan,FKIP UNMA.

Sugiyono. (2015). Metode Penelitian dan Pengembangan. Alfabeta.

Sultoni. (2015). Pengaruh perkembangan teknologi informasi terhadap hasil belajar mahasiswa ptik pada matakuliah algoritma dan pemrograman. 1(9). http://eprints.umsida.ac.id/683/1/Artikel ALPTKPTM.pdf

Sunardi, M., Ihwanudin, Ferry, DF. 2015. Pembelajaran Kolaboratif Berbasis Proyek: Inovasi Untuk Meningkatkan Kesesuaian Kompetensi Produktif Di SMK Dengan Kebutuhan Dunia Kerja. Seminar Nasional Teknologi Pendidikan UM, 2015,

Tal, T. (2013). Out-of-School: Learning Experiences, Teaching and Students' Learning. In In B. Fraser; K. Tobin \& C. McRobbie (Ed.). Second international handbook of science education (pp. 11091122). Springer.

Thomas, J. (n.d.). A Review of Research on Project -Based Learning. California: The Autodesk Foundation. 2000.

Widia. (2016). Pengaruh metode karya wisata terhadap Hasil belajar siswa tentang ekonomi Masyarakat sekitar. Universita(Kampus Tasikmalaya.). 